\title{
Local Fiscal Equalization in Estonia: Is a Reform Necessary?
}

\author{
Peter Friedrich \\ Chang Woon Nam \\ Janno Reiljan
}

\section{CESIFO WORKING PAPER NO. 2800 \\ CATEgory 1: Public FinAnCE \\ SEPTEMBER 2009}

\footnotetext{
An electronic version of the paper may be downloaded

- from the SSRN website: Www.SSRN.com

- from the RePEc website: Www.RePEc.org

- from the CESifo website: www.CESifo-group.org/wp
} 


\title{
Local Fiscal Equalization in Estonia: Is a Reform Necessary?
}

\begin{abstract}
Estonian municipalities should perform a broad range of functions, while their fiscal resources are often limited and large disparities in fiscal capacity prevail among them. Moreover, the power to regulate fiscal affairs is mostly in the hands of the central government. We discuss how a strict application of the connexity principle can protect municipalities from the fiscal bottleneck. We also recommend the introduction of the principle of parallelism and investigate its effects on the unconditional, down-flow grant system in Estonia. In particular the procedure of determining the total sum of block grants appears to be changed.
\end{abstract}

JEL Code: H27, H70, H77, R10.

Keywords: fiscal equalization, municipal finance, connexity, principles of parallelism, Estonia.

\author{
Peter Friedrich \\ University of Tartu \\ Narva Road 4 \\ 51009 Tartu \\ Estonia \\ Peter@mtk.ut.ee
}

Chang Woon Nam
Ifo Institute for Economic Research at the
University of Munich
Poschingerstrasse 5
81679 Munich
Germany
nam@ifo.de

Janno Reiljan

University of Tartu

Narva Road 4

51009 Tartu

Estonia

Janno.Reiljan@mtk.ut.ee 


\section{Introduction}

After a phase of transformation leading to a functioning private sector economy and the separate establishment of a public sector, a period of consolidation for the public sector is needed in new market economies. Estonia comprises a central government and municipalities as the sub-national jurisdictions. ${ }^{1}$ In part as a consequence of rather unbalanced regional development, the fiscal capacity gap among municipalities has gradually increased in this country during the last decade.

In Estonia all municipalities have to perform a broad range of functions, even though their fiscal resources are often seriously limited. In order to provide them with better chances in a fierce regional competition process, a more equitable financial endowment appears to be desirable as an initial condition for further local economic development. In addition new task requirements have to be met within the framework of the European Union, which in many cases are related to the minimum provision of infrastructure services for which the municipalities are responsible according to the Estonian constitution. Moreover, this fact bears some conflict potentials because the power to regulate fiscal affairs (concerning e.g. conditional grants and/or the size of the equalization funds for unconditional grants) is mostly in the hands of the central government, while the regulatory competence of the municipalities has remained rather weak. Therefore, among other issues, a well-functioning fiscal equalization system should be developed to encourage the local efforts to achieve fiscal balance, to improve fiscal autonomy and to support the public activities of municipalities. In particular, a more stable and predictable vertical equalization system appears to be urgently necessary in Estonia.

This study primarily aims at dealing with the following research topics:

(1) How has the existing Estonian vertical equalization system developed? What are its regional implications, strengths and weaknesses?

(2) Should the connexity principle and the principle of parallelism be chosen as the basis of reform?

\footnotetext{
${ }^{1}$ In Estonia, the municipalities consist of the cities (towns) and rural municipalities. In some cases the towns and their rural hinterlands form a mixed town-rural municipality.
} 
(3) How should the block grants (unconditional grants) be determined considering fiscal need and fiscal capacity indicators, and how could the principle of parallelism be introduced in this context?

(4) What are the effects on revenue changes that are led by the implementation of the parallelism for municipalities?

(5) Can we expect more balanced fiscal development of municipalities when applying the reform proposal?

This paper is structured as follows. After this introductory part, the first question is tackled in the second section. Information about the characteristics and problems of Estonian fiscal equalization is provided there as well. The application of basic principles as the reform recommendations and results will be discussed in the third section. The final section briefly summarizes the major findings of the paper and discusses the anticipated consequences of the reform and concludes.

\section{Estonian Fiscal Equalization System}

In Europe the parliament of a country generally has the obligation to provide the country's municipalities with sufficient financial resources to be used at their discretion within the framework of their powers. In addition, the need to protect financially weak local authorities calls for the fiscal equalization procedures which, however, do not diminish the discretionary powers of local authorities to perform their tasks of selfadministration. In Estonia, local government's responsibility areas are determined by the Local Governments Organization Act (KOKS, RT I 1993, 37, 558). Yet, the functions of local governments are not always explicitly described. According to a survey conducted by the Ministry of Internal Affairs, local government responsibilities have already been regulated in the mid-1990s by almost 450 different laws and legal acts that had assigned over 400 different tasks. 


\section{Figure 1 Functions and finance of municipalities in Estonia}

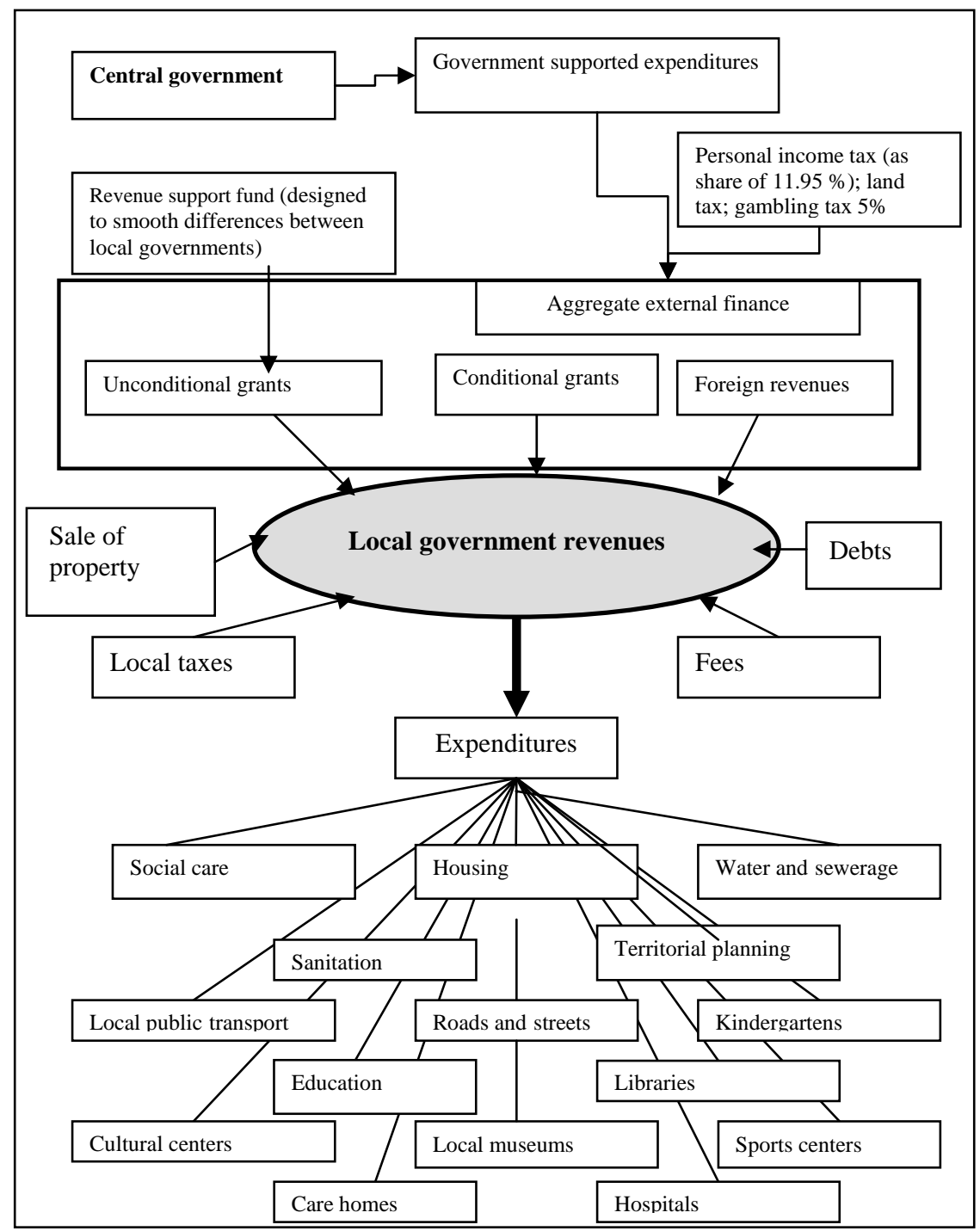

Source: Reiljan, Ramcke and Ukrainski (2006).

The main functions of Estonian local governments are explained in a systematic way in Reiljan at al. (2006). Estonian local government functions are relatively similar across counties (see Figure 1) but their fiscal strength greatly differs from one municipality to another. The share of tax revenues of all municipal revenues ${ }^{2}$ comprises approximately $47 \%$ of the total revenue of Estonian municipalities. Harju County leads the ranking with the share higher than 55\%, followed by Tartu County representing the share equal to the Estonian average. In South Estonia, the value only amounts to 32 to $34 \%$. In approximately half of all counties, tax revenues make up around 41 to $43 \%$ of total

\footnotetext{
${ }^{2}$ This relation is used to describe the fiscal autonomy (De Mello 2000).
} 
municipal and town revenues. The major source of the Estonian municipal tax revenue is personal income tax. ${ }^{3}$ The disparities between the share of per capita personal income tax receipts in municipal budgets in different Estonian counties and its Estonian average have become more apparent during the period 1997-2006. In Harju County, the share of per capita income tax receipt was around 36\% higher than the Estonian average in the period of 1997-2002, while its excess amounted to 31\% of the Estonian average for the period 2003-2006. The economic recession in Ida-Virumaa led to a drop of income tax receipts level from $73 \%$ in the period $1997-2006$ to $66 \%$ of the state average during the period 2003-2006. The counties in the eastern and southern parts of Estonia have experienced the lowest income tax receipts per inhabitant. The income tax share of all municipal revenues differs between the counties but its level presently reaches around 35 to $38 \%$ in the majority of Estonian counties. Analogously the share of other taxes ${ }^{4}$ of all municipal revenues also differs from one county to another.

The share of self-revenues (including taxes, sales, rents and interests received) of total municipal revenues also varies considerably in Estonia. For example, its share comprises approximately $80 \%$ in Harju County, whereas in South Estonia the share has remained at the 41 to $43 \%$ level. In most counties, the share makes up 50 to $55 \%$ of their total revenues. The regional dispersion of municipal income tax and the dispersion of total tax revenue (per inhabitant) decreased over time, while, the regional dispersion of self-revenue receipts grew slightly (see Table 1 ).

\footnotetext{
${ }^{3}$ Until 2002, 56\% of all income tax collected was given to the municipalities and $44 \%$ to the central government. During last years, the major tax policy objective was to reduce direct taxes and replace them by indirect taxes in Estonia. The personal income tax rate has been gradually reduced from $26 \%$ to $21 \%$ (from 2004 to 2009). Consequently the municipal share of income tax amounted to $11.4 \%$ of gross income in 2004, while the share grew to $11.9 \%$ in 2009 . All tax allowances, e.g. for interest rates, costs for education and private retirement savings, are made from the central government's portion of income tax, which was $14.6 \%$ of gross income in 2004 and 9.1\% in 2009. Because of the fiscal problems related to the central government budget the reduction of personal income tax rate was stopped in February 2009. As a consequence the share of municipalities was reduced to $11.4 \%$, whereas the central government's share increased to $9.6 \%$.

${ }^{4}$ Municipalities in Estonia also collect land tax and they have the right to enforce its rate between 1 to $2.5 \%$ on the land value basis. Many municipalities use the right to waive land tax on residential land owned by pensioners for their own use. Land tax in most cases makes up around 2 to $4 \%$ of total municipal revenues. Moreover Estonian municipalities have the right to establish local taxes, e.g. gambling tax, land tax, local sales tax, municipal boat tax, advertisement tax, tax for closing of streets, etc. Local taxes on average amount to less than $1 \%$ of municipal budgets in Estonia.
} 
Table 1 Regional dispersion of municipal self-revenues, tax revenues and personal income tax receipts compared to the national average for the periods 1997-2002 and 2003-2006

\begin{tabular}{|l|c|c|c|c|c|c|}
\hline & $\begin{array}{c}\text { Self- } \\
\text { revenue } \\
1997-\end{array}$ & $\begin{array}{c}\text { Self- } \\
\text { revenue } \\
2003-\end{array}$ & $\begin{array}{c}\text { Tax } \\
\text { revenue } \\
1997-\end{array}$ & $\begin{array}{c}\text { Tax } \\
\text { revenue } \\
2003-\end{array}$ & $\begin{array}{c}\text { Personal } \\
\text { income } \\
\text { tax } \\
\text { revenue } \\
1997- \\
2006\end{array}$ & $\begin{array}{c}\text { Personal } \\
\text { income tax } \\
\text { revenue } \\
2003-2006\end{array}$ \\
\hline $\begin{array}{l}\text { National } \\
\text { average } \\
\text { dispersion* }\end{array}$ & 2002 & 2002 & & & & \\
\hline
\end{tabular}

* Measured in terms of standard deviations.

Source: Authors’ calculations

The share of state budget grants of total municipal revenues increased remarkably, from $25 \%$ in $1997-2002$ to $35 \%$ in $2003-2006$. Since the equalization fund resources (with the share of approx. 7\%) remained stable, this fact in turn indicates that the share of conditional grants grew also steadily, from $18 \%$ to $28 \%$ in municipal total expenditures. State budget grants are of the greatest importance for municipal budgets in South Estonia, shown by the share amounted to over 55\% in 2003-2006. In Harju County, grants from the state budget made up a substantially lower share of total municipal expenditure, reaching approximately 10\% in the period 1997-2002 and 20\% in 2003-2006. In the latter period the conditional grants ${ }^{5}$ contributed to the increase in the relative revenue level by more than $14 \%$ compared to the national average in five counties, while the drop in Harju County accounted for around the similar extent. The significance of conditional grants on the relative revenue level in rural municipalities and towns in Pärnu and Ida-Viru counties has been quite low.

The share of unconditional grants (block grants) of the total volume of central government grants to municipalities dropped from $28 \%$ in $1997-2002$ to $21 \%$ in $2003-$ 2006. The share only rose in Hiiu County (from $18 \%$ to more than $25 \%$ between these two periods). Despite some reduction, equalization grants accounted for 35\% of total grants in Ida-Viru County and $30-31 \%$ in counties in South Estonia. The equalization

\footnotetext{
${ }^{5}$ The majority is given to municipalities to cover specific conditional tasks - paying comprehensive school teachers' salaries, buying textbooks and making investments, paying social aid, (partially) covering school lunches and supporting the living environment on small islands (see below).
} 
fund has been playing a remarkable role ${ }^{6}$ for the local finance of more than $90 \%$ of all municipalities. Regionally, the importance of the equalization fund varies remarkably. About $17 \%$ of total revenues in rural municipalities in counties in East and South Estonia are presently endowed with the equalization fund provisions. The per capita unconditional revenues after the equalization currently vary by $24 \%$ on average, with some exceptional cases like $100 \%$ in Hiiu County and $76 \%$ in Ida-Viru and Valga counties. The effect of equalization fund provisions on unconditional budgetary municipal resources of counties compared to the national average ranges from 24 to $27 \%$ in southern Estonia. The impact of the equalization fund on income growth is also remarkable in counties located in eastern Estonia. The loan capacity as the relationship between contracted loans and self-revenues has fallen in the majority (around 60\%) of counties and risen in the rest share of counties during the last ten years. Many municipalities finance their expenditures, especially investments, by borrowing.

For the fiscal equalization of Estonian municipalities and coverage of expenditure needs with revenues, the central government plays a leading role. According to $\S 154$ of the Estonian Constitution, the municipalities which operate independently according to the law, decide and organise all elements of life in the local area. The same paragraph describes the basis for financing these functions as follows: "municipalities can be obligated to fulfil tasks only via law or in agreement with the municipality. Expenses connected with tasks designated to the municipality by law will be financed from the state budget”. So it is clear that the Estonian Constitution does not provide financial autonomy through an independent tax base for the municipalities. The $\S 160$ of the Estonian Constitution notes, “...the law will resolve management issues in the municipality and the supervision of its activities” (Eesti Vabariigi põhiseadus 1992).

In the Law of Municipal Financial Management currently adopted by parliament, the Ministry of Finance follows the approach that says the state can intervene in municipal activities, including the prescription of ways how local issues should be managed (eletuskiri kohaliku omavalitsuse üksuse finantsjuhtimise seaduse

\footnotetext{
${ }^{6}$ Deciding over the size of the equalization fund could be seen as a financial instrument for increasing the administrative power of the central government. Less than $10 \%$ of all local governments have sufficient self-revenues and they are not dependent on the central government's balancing support. The question arises whether such an equalization amount does not stimulate a municipal dependent mentality and weakens their own attempts for raising their own revenue (for instance supporting entrepreneurship development etc.).
} 
eelnõu juurdeseletu 2008). The Ministry of Finance also concludes that the European Charter of Local Self-Government does not exclude the option of control over the rationale of municipal activities, when this is balanced with the importance of interests that need to be protected. Paragraph $\S 9$ of the State Budget Law defines the relationship between the state budget and municipal budgets, supporting the ideas given in the Constitution and specifies: "grants from the state budget are passed to the municipal budget via (1) the equalization budget fund; or (2) specific purpose-oriented (conditional) grants”. The equalization funds provide the municipalities with block grants (Riigieelarve seadus 1999).

Paragraph $\S 5$ on "Revenues of Budget” of the Law of Rural Municipal and Town Budgets provides a list of municipal revenue sources on the basis of their economic content (Valla ja linnaeelarve seadus 1993): (1) taxes; (2) sales of goods and services (including user charges); (3) (one-time) sales of material and immaterial assets; (4) income from assets; (5) financial supports including foreign aids; and (6) other revenues including fines. The state budget as the source of revenues for municipalities and towns is related to the fifth item of the above list, because remarkable supports can originate only from the state budget in most cases. Paragraph $\S 8$ of the same law establishes the options for contracting a loan: rural municipalities and towns can borrow, use capital rent, issue bonds and contract other liabilities. ${ }^{7}$

The Law of the Relationship between Towns or Rural Municipalities and the State Budget presents in $\S 1$ the objective of the law which is "to determine the basis for the provision of funds from the state budget to town and rural municipal budgets and also the principles of balancing those budgets”. According to $\S 2$ of this law, conditional grants have primarily been provided in the fields such as salaries for teachers, family doctors, the social tax and unemployment insurance tax connected to those salaries; investments and expenditure connected with the public responsibilities of municipalities according to the law. In $\S 2$ and $\S 4$ the same law refers to the objective of budgetary balance - state budget grants are made in order to "complement budget revenues". ${ }^{8}$

\footnotetext{
${ }^{7}$ In the law there are fixed strict restrictions for local borrowings.

8 "Funding provided in order to increase the local income together with other state budget grants and tax revenues should ensure that the town or rural municipality fulfils its responsibilities as set by the law” ( $\$ 4$ of Valla- ja linneaeelarve seadus 1994).
} 
Following §9, there is a support fund in the state budget to cover revenue deficits in rural municipal and town budgets.

The mechanism for verifying the need for budgetary support for rural municipalities and towns given in $\S 4$ of this law and in $\S 9$ of the State Budget Law seems at first glance to aim at balancing the interests of the central government and the municipalities: the necessary sum to increase local budget revenues will be determined by negotiations between a state institution appointed by the central government and the municipalities or their unions. However, in the case that an agreement is not reached, the size of that sum is determined by the government in the state budget. Paragraph $\S 9$ of the State Budget Law says that "the division of resources in the municipalities budget support fund is carried out according to a procedure and in amounts specified by the government”. Uniform criteria for the allocation of (unconditional) equalization fund and conditional grants among municipalities have been set by the Ministry of Finance and these are adjusted to the current economic situation every year when preparing the state budget.

Unions of municipalities are weak institutions with only a few officials, and cannot analyse or dispute the rules governing municipal budget supplements or the calculation methods developed by ministries with hundreds of civil servants. Currently, there is no founded method to assess the expenditures connected with tasks legally designated to the municipalities. There is no basis for assessing the different opinions during the negotiations between the central government and the municipal representatives. The specification of investment support has been totally left to the free political choice of the parliament and the central government, which in turn means that the municipalities are directly dependent on the central government's decision. The municipal fiscal autonomy is rather restricted in Estonia.

Further restrictions of fiscal autonomy stem from the potential for the central government to intervene in the performance of local activities, the tendency to include the debts of municipal enterprise in the volume of debts allowed to a municipality and the formulation of need indicators for block grants. In Estonia, several "expenditure needs” criteria are applied: (i) the number of children in two different age groups, (ii) the number of people in the workforce age, (iii) the number of pension-aged people, and to a lesser extent, (iv) the number of people in palliative care as well as (v) the total 
length of local roads (streets) expressed in kilometres. The choice of such need indicators are mainly under the control of the Ministry of Finance thus increasing dependence of municipalities on the central government. The central government can assist municipalities by increasing the personal income tax rate. However, this policy does not help municipalities under fiscal stress much, since the personal income tax base in the economically distressed areas tends to be narrow. The fiscal conditions of municipal development in Estonia are to a large extent fixed by the fiscal equalization policy of the central government.

Estonian municipalities are generally characterised as being insufficiently funded, having a dependant mentality, struggling to obtain a larger share of the state budget grants and lacking in motivation to find alternative measures for revenue growth (Ulst 2000). In the fast economic growth phase between 2001 and 2007 the fiscal situation of the municipalities gradually improved, but during the current economic and financial crisis the central government of Estonia introduced the shortening of municipal support funds and even cuts of local participation in tax receipts (see Figure 1) to safeguard the central government budget.

At present information and research concerning the 'actual' expenditure needs of municipalities lack in Estonia which can be applied as a basis for equalization purposes when granting the down-flow unconditional transfers. Only a calculation of normative expenditure based on general characteristics of a municipality exists. However, to specify conditional grants, actual expenditure needs of municipalities should ideally be considered when accounting the size of a conditional grant.

A comparison of municipal fiscal data of EU member states suggests that the situation in Estonia does not much differ from that in other European countries. In particular, two indicators are of interest for the comparison: (a) the financial means available to perform municipal tasks expressed by municipal budget expenditure in relation to country's GDP and (b) the fiscal position in relation to higher governments indicated by municipal expenditure as a percentage of total government sector expenditure. In 2007 the proportion of Estonian GDP $(=8.4 \%)$ that the municipalities can use was a quarter less compared to the average value for the EU27 (11.2\%). ${ }^{9}$ At the

\footnotetext{
${ }^{9}$ Often there are more than two government levels in the larger countries, and when financing the public activities, the relationships between different government tiers must be resolved within a country (see Lenk 2008).
} 
same time, in Estonia the share of municipal expenditures of total government expenditures was at the EU average level (= 26.1\% compared to the EU27 average of $24.5 \%$ in 2007). In Scandinavian countries the share of local government expenditures as a percentage of total government expenditures amounted from 40 to $63 \%$. Compared to other new EU member states Estonia achieves the same ranking with the Czech Republic.

Therefore, the main weakness related to the fiscal stress in Estonia does not primarily concern the size of municipal expenditures - although this could be higher because of the needs for local infrastructure - but the fiscal equalization, the autonomy of municipalities and the regional dispersion of expenditures seem to be in a more serious situation. To reduce these regional divergences, to increase and protect the fiscal autonomy of municipalities, and also to decrease local government dependencies on political constellations in the central government, an improvement of the fiscal equalization system in Estonia appears to be necessary.

\section{$3 \quad$ Guiding Principles for Changing Fiscal Equalization}

\subsection{The Connexity Principle}

One group of principles that has to be introduced to stabilize the autonomy and competences of municipalities relates to the so-called connexity principle. This principle states that an imputation of a new function or a reallocation of functions from the central government to the municipalities is only allowed if the central government provides the municipalities with the necessary means to perform the function successfully (Zimmermann 1999). In some EU member countries the downward shift of public tasks from a higher government to a municipal level has quite often taken place while leaving the fiscal burden to the municipalities. In addition, the assignments of public activities and their finance formulated in constitutions have also often been unclear in some countries including Estonia. Although the subsidiarity principle has been widely acknowledged as a mechanism to protect the lower-level government and its activities, solely municipal tasks have been defined in this context, while the 
discussion about the ways of safeguarding the municipal fiscal autonomy to finance the assigned local activities has often been lacking.

In some state constitutions of the German Länder the connexity principle is fixed. Consequently the states shifting the tasks to the municipalities should cover the administration costs of these tasks. But it is still controversial to what extent the municipalities should get compensated financially. Sometimes difficulties also arise because municipalities might be unprotected by the federal government which is the case in Germany. In this country municipalities can bring the related disputes only to their own state court. Only in cooporation with the state constitutional court can a case be brought to the federal constitutional court as well. In a rather few exceptional cases the matter can be treated and discussed before a European court. Or - if a connexity principle is formulated under the present conditions in Estonia - the central government has legal possibilities to influence the volume and allocation of municipal expenses and their finance.

Repeatedly, if the connexity principle applies, the central government should take over the administrative costs of the tasks transferred to the local governments. In this context another question arises about the ways how to identify these costs. As municipalities have the organizational autonomy, they are able to determine these costs through the selection of cost assessment, distribution, and calculation methods. Therefore, they can influence the cost estimation process, which would lead to the determination of higher costs that should be then compensated by the central government. Another possibility to be applied would be to assign standard costs. But to what types of municipality should these standard costs refer? It is also questionable whether the municipalities may perform the task transferred to them (as their own activity) in an adequate way. Otherwise the task fulfilment is just an administrative act executed for the central government. Therefore, doubts will emerge with respect to the appropriate costs to be compensated.

A debate on fair costs is likely to end up with a standard cost formulation. In this theoretical framework a vertical principal-agent game between municipalities (as a group or individual municipalities) and the state ministry of finance (as representative of the central government) will take place. There might also be a Nash solution between the negotiating partners, or a powerful central government leaves the municipalities at 
their minimum utility that is just high enough to execute the local function assigned. This is shown in the Diagram (a) of Figure 2 with the curve $U C G$ showing total utility of the central government (if it carries out the public activity alone) and the curve UminM demonstrating the minimum utility of a municipality that gets higher with the level of local service activities $X$. The net utility of central government is just the difference between the value of $U C G$ and $U \min M$ of a service volume $X$. The best task performance that the central government can achieve is the point where marginal total utility equals marginal minimum utility of a municipality (Gravelle and Rees 1992).

The standard cost in the sense of central government should be determined in such a way that this solution is achieved. There is a danger that financial means given to the municipalities turn out to be rather small. As a consequence, other selfadministrative tasks of the municipalities get hindered or become unfeasible. Another solution would be to maximize the total utility (see the Diagram (b) of Figure 2). In this case the solution will be an activity level where the marginal total benefit becomes zero. With a powerful central government the municipalities can still be kept on their minimum level path, however, the activity level (i.e. the task performance) as the maximum of total utility outcome is higher than that in the case of maximizing total utility minus the minimum utility of the municipalities - see Diagram (a) of Figure 2. Yet the gains between the central government and the municipalities have to be distributed through the definition of standard costs and payments to cover them. In the case of negotiations where the municipalities possess more power, a Nash solution maximizing the product of differences between utility and minimum utility of both partners will be achieved. ${ }^{10}$

If risks are considered when deriving a solution, one may better turn to the traditional principle-agent models (Gravelle and Rees 1992). If the central government takes risks with respect to the activity results of the municipalities while having information about the amount of local activities, a constant payment just for performance of tasks is the best compensation scheme for the central government. If the activities of the municipalities cannot be detected properly the payment of central government should increase as the activity levels grow.

\footnotetext{
${ }^{10}(U C G-U \min C G) *(U M-U \min M) \rightarrow \max$, where $U M$ denotes the utility of a municipality (see also Friedrich, Gwiazda and Nam 2004).
} 
Figure 2 Vertical principal-agent game between a model municipality and the central government

Diagram (a)

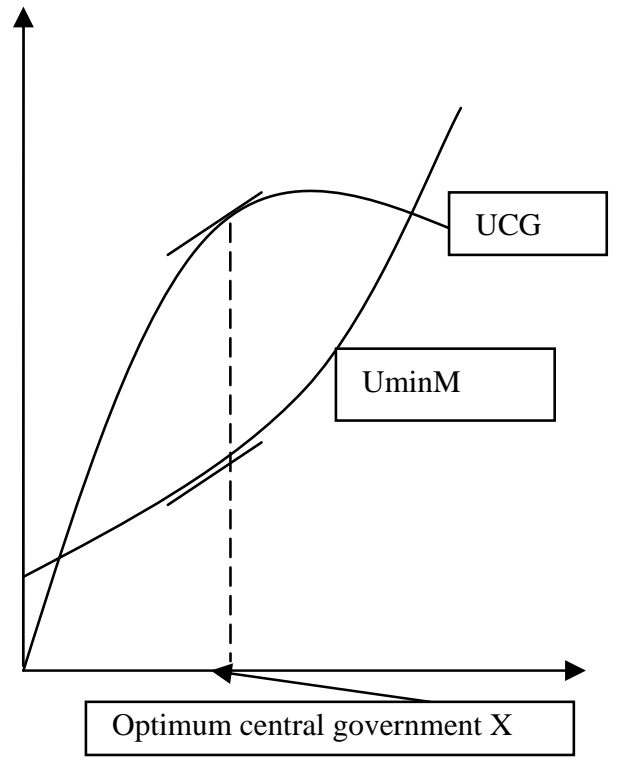

Diagram (b)

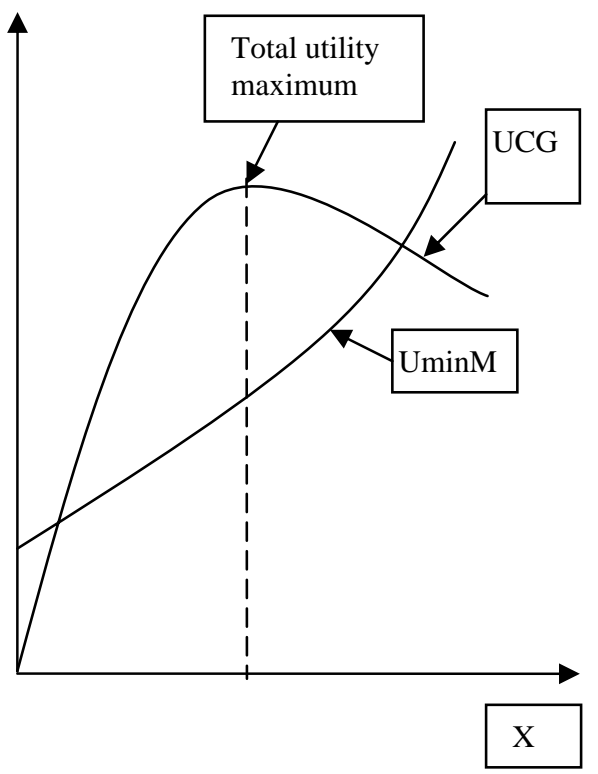

Source: Authors' conception.

We argued here in terms of the utility. However, the utility can be expressed differently according to individual goals (such as health, education, environment, transportation, safety, etc.), economic goals like employment, social goals, etc. (Eichhorn and Friedrich 1976). The models should be modified with respect to these various goals to be achieved. For example, the utility can be expressed by employment as a central government goal and ensuring minimum employment in a community as the local goal. There may also be a bundle of goals including political ones where the result depends on different mixes of the goals as well leading to quite different compensations. An indicator of social welfare like net-benefit may be used as well, encountering the difficulty that a nationwide social welfare differs from the local welfare of the citizens of a municipality.

The financial means to compensate municipalities' expenditures related to their activities should ideally be transferred through conditional grants. Funding these functions by block grants, which all Estonian municipalities do not receive, should be limited. Some municipalities would be excluded from the compensation according to 
the connexity principle. ${ }^{11}$ Other communities might minimize the performance of the new or transferred tasks in order to improve the services of pure self-administration by the unconditioned grant.

The character of public activities to be transferred should be determined and described in terms of certain appropriate criteria. A basic research program should be developed to identify such criteria, also referring to some organizational indicators of management capacities of such municipalities, and including the potentials of other types of local institutions such as cross-municipal associations like the FOCJ (Functional Overlapping competing Jurisdiction) to perform such municipal functions (Friedrich and Reiljan 2008). Towns endowed with some special functions in regional and urban planning with regard to environment, tourist centres, water protection, industries, transportation, etc. might be included in the criteria list.

When realizing the connexity concept, some sub-principles related to its legal stipulation should also be kept in mind (Zimmermann 1999; Blankart and Borck 2004; Friedrich, Gwiazda and Nam 2004). First of all, the connexity principle should be formulated in detail in the constitution and adequately considered in laws related to the intergovernmental fiscal relations between the different government tiers. Its consideration should be then enforced through the cases and decisions of the constitutional court of Estonia. A specification of the connexity principle has to deal with EU tasks or central government tasks that are under the direct control of the EU. It might be stipulated that the EU itself or the central government has to compensate municipalities. The compensation scheme for task transfers and fiscal assistances should also consider the subsidization schemes laid down in laws or general decrees. These measures could also be accompanied by strengthening municipalities’ political power by providing a wider scope of local decision making competences in negotiations concerning the vertical public task transfers (Friedrich, Gwiazda and Nam 2004).

\footnotetext{
${ }^{11}$ The inclusion of 'people in palliative care' to the expenditure need indicators in Estonia since 2006 is related to the fact that the responsibility for this task was handed over from the central government to the municipalities and the equalization fund was increased. Two problems emerged, however. Firstly, for those municipalities not receiving a share of the equalization fund, their legitimate right to obtain extra financial means for an additional task is being violated. Secondly, resources intended to fulfill a certain task cannot be connected with the equalization fund principle.
} 


\subsection{The Principle of Parallelism}

The vertical fiscal relation between central government and municipalities is a crucial issue in Estonia. The amount of financial grants addressed to the individual municipalities depends on the total sum of money devoted to such intergovernmental transfers. This is called the equalization fund in Estonia. There should be a law defining the conditions for the content and size of the equalization funds. This has to express general rules of equalization funds formation whereas individual conditions could be fixed in a yearly fiscal equalization law. That means that the financial sources for this purpose should be stated as a percentage share of specified revenues of the central government, and in addition concerning public debts incurred by the central government. The relationship between block grants and conditional grants should leave a minimum share for block grants. However, the volume of the equalization fund should be in line with the principle of parallelism.

We suggest the implementation of Saxon style principle of parallelism between the central government and the municipalities in Estonia. It says that the development of disposable municipal revenues should be in parallel with the central government's disposable revenue. In order to safeguard the finance of self-administration in municipalities there should be a parallel development of own resources of central government and of municipalities. Politicians are obliged to consider such a parallelism when they determine the equalization funds for block grants. Exemptions from this principle should only be allowed according to the specifications in the law concerning war, epidemics, deep economic crises, natural disasters, serious demographic difficulties, etc. A crucial problem to be solved is the definition of relevant own disposable revenues. To define disposable revenues one may turn to the cash flow that is at the disposal of central government or at the disposal of municipalities. Such a cash flow which is used in Germany to measure the fiscal possibilities and situation of municipalities refers to all revenues minus the inevitable expenses of the municipality. This indicator is named 'free top (freie Spitze)'. For the central government, an additional question also emerges, whether down-flow grants to municipalities become part of the inevitable expenditures of the central government or not. As they are not available to the central government they should be deducted. The central government of Estonia receives tax revenues from own taxes, shared taxes, payments from the EU, 
revenues from fees, sanctions, borrowings, sales of state property, dividends of central state enterprises, $25 \%$ of customs duties and other revenues. Yet the customs revenues are exclusively transmitted to the EU. Service fees are formed primarily according to the cost coverage and benefit principle. Since they mostly do not increase the financial scope of the central government, they should be excluded as well. Profits received from the Estonian central bank should be included (see Friedrich and Ramke 2007).

Again for the municipalities, tax revenues consist of their own resources as well as revenues from concessions. Dividends of municipal enterprises can be included in the own resource criteria, too. Payments of sanctions to the municipalities increase also the own fiscal resources. Unlike the conditional grants, the block, unconditional grants increase the own financial revenues. Revenues from fees, public debt and property sale should be excluded as already mentioned above. Donations by private individuals that are not related to the additional municipal expenses can be added, too. If they are linked to additional expenses, e.g. construction or renewal of a building to host an art collection, the net fiscal inflow may also be added.

In Estonia a formula for the intergovernmental fiscal equalization exists already. The formula for calculating the amount of the down-flow subsidy ( $T n$ ) aimed at supporting the achievement of local governments balance can be expressed as the difference between the normative revenue and the expenditure levels:

$$
T n=(a k-a n) * 0.9
$$

where:

- an means the normative level of revenues from personal income tax, land tax and charges for the use of natural resources that go to the budget of a local government unit in a given budget year ${ }^{12}$;

- $\quad a k$ denotes the level of normatively calculated demand for payments (costs) of a municipal budget in a given fiscal year ${ }^{13}$; and

\footnotetext{
${ }^{12}$ The normative municipal revenue level (i.e. the capacity indicator an) is the product of the following three local revenue data: (1) personal income tax receipts for the last three years, which is multiplied by the income tax accounting growth rate coefficient (i.e. two thirds of the average coefficient of income tax growth for the last two years); (2) accounting land tax sum, using the land tax rate of $1.25 \%$ (the municipality can establish the land tax rate within a range between 1 to 2.5\%); and (3) prognosis of received charges for the use of natural resources.
} 
- 0.9 indicates that block grants have to cover $90 \%$ of the difference between the normative revenues and normative expenditures.

The calculation of the normative expenditure demand in municipalities involves a process of harmonizing two dimensions. On the one side, the forecasted level of municipal revenue from taxes and charges on the use of natural resources is found using the above mentioned self-revenue sources. On the other side, negotiations between the central government and the municipalities result in a political decision reflected in the State Budget Law about the size of equalization fund which is designed to help reduce municipal and town budget deficits in the corresponding budget year.

For the individual municipalities the calculated normative revenues are firstly compared to the normative expenditure needs, and then the negative results (i.e. the revenue deficits) are added together for all municipalities suffering from the fiscal stress. The total sum of municipal revenue deficits will be then multiplied by the factor 0.9 and the outcome of this computation should be the same as the sum of the equalization fund politically set. Formally expressed, the revenue deficits for covering the normative costs of all rural municipalities and towns are compensated via the central government grants by exactly $90 \%$.

Table 2 depicts a thorough modification of the expenditure coefficients in 2004: those for the indicators like '7-18 years old children', '65 years old and older' and 'volume of roads' increased while those for others declined. Since 2005 expenditure coefficients increased gradually for all the need indicators. When calculating the growth rate of the expenditure coefficient, the normative municipal revenue growth has been taken into account so that the equalization fund would cover exactly $90 \%$ of the normative revenue deficit. ${ }^{14}$ Once again one should note that this is solely an equation applied for the entire sum of equalization fund among municipalities and it does not

\footnotetext{
${ }^{13}$ The normative level of municipal budget expenditures (i.e. the needs indicator $a k$ ) is calculated by multiplying cost formation indicators with the cost coefficient connected with the indicator unit. As a cost formation basis the following indicators are viewed: (1) the number of 0-6 years old children; (2) the number of 7-18 years old children; (3) the number of 19-64 years old workforce; (4) the number of 65 years old and older; (5) the length of roads (streets in $\mathrm{km}$ ); and (6) the number of people in palliative care. ${ }^{14}$ When using the equalization fund to cover $90 \%$ of the municipal or town normative revenue deficit, the task of unifying the financing for public sector services is fulfilled quite well. Assume that there are two municipalities and the normative revenues of the first municipality cover $90 \%$ of the normative expenditure demand whereas the coverage share amounts to $50 \%$ for the second municipality. By the given $90 \%$ equalization coefficient, the first one gets $9 \%$ compensation from the equalization fund and the other gets $45 \%$ of the normative expenditure demand. After such an adjustment, the coverage rate of the normative expenditures increases to $99 \%$ for the first municipality and to $95 \%$ for the second.
} 
deal with the actual expenditure demand and revenue surplus or the deficit assessment problem. Less than $10 \%$ of all municipalities - mainly from Harju County (including the capital Tallinn) and Ida-Viru County (rural municipalities with high receipts from oil shale mining) - have their normative revenues higher than their normative expenditure needs. Those municipalities are left out of the division of the equalization fund.

Table 2 Expenditure coefficients per expenditure indicator unit used for municipal normative expenditure level assessment (in thousands of kroons)

\begin{tabular}{|l|c|c|c|c|c|c|c|}
\hline $\begin{array}{l}\text { Expenditure } \\
\text { indicators }\end{array}$ & \multicolumn{7}{|c|}{$\begin{array}{c}\text { Expenditure coefficients per indicator unit } \\
\text { (in thousands of Estonian kroons) }\end{array}$} \\
\hline & 2003 & 2004 & 2005 & 2006 & 2007 & 2008 & 2009 \\
\hline 0-6 years old & 13.228 & 8.422 & 9.473 & 10.727 & 13.146 & 15.282 & 17.391 \\
\hline 7-18 years old & 2.231 & 6.698 & 7.533 & 8.530 & 10.454 & 12.152 & 13.829 \\
\hline 19-64 years old & 4.973 & 2.818 & 3.170 & 3.590 & 4.330 & 5.033 & 5.728 \\
\hline $\begin{array}{l}\text { 65 years old and } \\
\text { older }\end{array}$ & 3.302 & 4.094 & 4.605 & 5.214 & 6.290 & 7.312 & 8.321 \\
\hline $\begin{array}{l}\text { volume of roads } \\
\text { (streets), km }\end{array}$ & 4.264 & 29.103 & 32.734 & 37.065 & 44.710 & 51.973 & 59.145 \\
\hline $\begin{array}{l}\text { people in } \\
\text { palliative care }\end{array}$ & & & - & 7.000 & 8.444 & 9.816 & 11.170 \\
\hline
\end{tabular}

Source: Ministry of finance adjustment fund calculations 2003-2009, collected by authors.

The parallelism has not yet been considered in Estonian fiscal equalization system because: (1) the total sum of block grants determined annually has been the result of political decision of parliament about the state budget; and (2) the central government has changed the relations of the expenditure coefficients and, by doing so, also the expenditure level assessment of the individual municipalities.

Friedrich et al. (2004) have shown how in Saxony the principle of parallelism is integrated into the model of vertical fiscal equalization between the state and its municipalities. Analogously, the concept of parallelism concerns the municipalities' disposable income $E G_{t}$ and the provided intergovernmental transfers (by the central government) $S Z_{t}$. The disposable revenue by the central government is $E L_{t}$. From this disposable income we deduct the down-flow grants from the central government to municipalities $S Z_{t}$. The size of the intergovernmental transfers is fixed in the period of 
zero $(t=0)$ at a certain percentage share of the disposable income of the central government (see also Nam, Parsche and Steinherr 2001).

$$
\frac{E G_{t}+S Z_{t}}{E G_{t-1}+S Z_{t-1}}=\frac{E L_{t}-S Z_{t}}{E L_{t-1}-S Z_{t-1}}
$$

The size of parallelism can be expressed by

$$
\left(E G_{0}+S Z_{0}\right) /\left(E L_{0}-S Z_{0}\right)
$$

The rearrangement of equation (1) leads to

$$
S Z_{t}=E L_{t} \cdot\left(\frac{E G_{t-1}+S Z_{t-1}}{E G_{t-1}+E L_{t-1}}\right)-E G_{t} \cdot\left(\frac{E L_{t-1}-S Z_{t-1}}{E G_{t-1}+E L_{t-1}}\right)
$$

and analogously

$$
S Z_{t}=E L_{t} \cdot\left(\frac{E G_{0}+S Z_{0}}{E L_{0}+E G_{0}}\right)-E G_{t} \cdot\left(\frac{E L_{0}-S Z_{0}}{E L_{0}+E G_{0}}\right)
$$

If equation 4 is used to account the block grants for Estonian municipalities we achieve the results in Table 3. 
Table 3 Calculations of the parallelism for block grants in Estonia

\begin{tabular}{|c|c|c|c|c|c|c|c|c|c|c|}
\hline & $\begin{array}{c}\text { EL - Central } \\
\text { government } \\
\text { disposable } \\
\text { revenues } \\
\text { (million kr) } \\
(1) \\
\end{array}$ & $\begin{array}{l}\text { EG - Local } \\
\text { government } \\
\text { disposable } \\
\text { revenues } \\
\text { (million kr) } \\
(2) \\
\end{array}$ & $\begin{array}{l}\text { SZ Block } \\
\text { grants } \\
\text { sum } \\
\text { (million } \\
\text { kr) } \\
(3) \\
\end{array}$ & $\begin{array}{c}\text { EL + } \\
\text { EG } \\
(4) \\
\end{array}$ & $\begin{array}{c}E G+S Z \\
(5)\end{array}$ & $\begin{array}{c}E L-S Z \\
(6)\end{array}$ & $\begin{array}{c}(\mathrm{EG}+\mathrm{SZ}) / \\
(\mathrm{EL}+\mathrm{EG}) \\
(7)\end{array}$ & $\begin{array}{c}(\mathrm{EL}-\mathrm{SZ}) / \\
(\mathrm{EL}+\mathrm{EG}) \\
(8)\end{array}$ & $\begin{array}{c}\text { SZ } \\
\text { parallelism } \\
1997 \\
\text { (million kr) } \\
(9) \\
\end{array}$ & $\begin{array}{c}\text { SZ } \\
\text { parallelism } \\
2002 \\
\text { (million kr) } \\
(10) \\
\end{array}$ \\
\hline 1997 & $\underline{13660}$ & $\underline{3441.4}$ & $\underline{704.79}$ & $\underline{17102}$ & $\underline{4146.2}$ & $\underline{12955}$ & $\underline{0.2424}$ & $\underline{0.7576}$ & & \\
\hline 1998 & 14952 & 3956.2 & 695.69 & 18908 & 4651.9 & 14256 & 0.246 & 0.754 & 627.9 & \\
\hline 1999 & 14679 & 4155.1 & 736.8 & 18834 & 4891.9 & 13942 & 0.2597 & 0.7403 & 411.08 & \\
\hline 2000 & 16342 & 4213.3 & 866.5 & 20555 & 5079.8 & 15475 & 0.2471 & 0.7529 & 770.16 & \\
\hline 2001 & 18018 & 4636.5 & 951.8 & 22654 & 5588.3 & 17066 & 0.2467 & 0.7533 & 855.9 & \\
\hline$\underline{\underline{2002}}$ & $\underline{\underline{21018}}$ & $\underline{5246.8}$ & $\underline{1153.3}$ & $\underline{\underline{26265}}$ & $\underline{6400.1}$ & $\underline{19865}$ & $\underline{0.2437}$ & $\underline{0.7563}$ & 1121 & \\
\hline 2003 & 23965 & 5595.2 & 1150.4 & 29560 & 6745.6 & 22814 & 0.2282 & 0.7718 & 1571.5 & 1607.9 \\
\hline 2004 & 26402 & 6309.3 & 987.83 & 32712 & 7297.1 & 25414 & 0.2231 & 0.7769 & 1621.5 & 1661.8 \\
\hline 2005 & 30492 & 7144.6 & 1000.5 & 37636 & 8145.1 & 29491 & 0.2164 & 0.7836 & 1980.2 & 2026.5 \\
\hline 2006 & 37268 & 8777.8 & 1143.8 & 46046 & 9921.6 & 36124 & 0.2155 & 0.7845 & 2385.9 & 2442.6 \\
\hline 2007 & 46098 & 10974 & 1430 & 57072 & 12404 & 44668 & 0.2173 & 0.7827 & 2862.5 & 2932.8 \\
\hline 2008 & 42737 & 12837 & 1347.2 & 55574 & 14184 & 41390 & 0.2552 & 0.7448 & 636.73 & 705.17 \\
\hline
\end{tabular}

Note: 1997 and 2002 are reference years for the parallelism.

Source: Authors' calculations. 
The first attempt refers to the year 1997 as a base year. Column (3) of Table 3 shows the actual block grants and column (9) the block grants under the parallelism. The results reveal that under the parallelism conditions of 1997, the block grants paid would have been lower than the actual ones. However, since 2002 the block grants under the parallelism would have been considerably higher than the actually paid ones. In 2008 the economic recession tended to affect the municipalities seriously. As shown in column (10), similar results are also obtained if the conditions of 2002 are used as reference for the parallelism. Under the parallelism both levels of governments are gaining from a prosperous economic development and vice versa. Until 2009 the yearly actual total block grants $S Z_{t}$ were determined in Estonia as a result of parliament decision about the central government budget. Under the prevailing conditions a paternalistic central government can protect the municipalities but also expand its influence on the costs of municipalities. The parallelism solution gives the municipalities a larger scope of autonomy to perform their own tasks if block grants and referring tasks are strictly separated from the conditional grants: The latter ones should be paid only to finance the transferred local tasks and to support some selfadministration tasks which seem to be important from the central government's point of view.

The parallelism can also be integrated into the Estonian block grant assignment system as well. The block grants of a municipality $i$ at year $t$ amount to

$$
S Z_{i t}=\left(a k_{i t}-a n_{i t}\right) * 0.9 \text {, if } a k_{i t}>a n_{i t} \text { and } 0 \text { if } a k_{i t}<a n_{i t}
$$

For the total sum of block grants must hold:

$$
S Z_{t}=\underset{j}{\left(\sum_{j} a k_{j t}-\sum_{j} a n_{j t}\right) * 0.9}
$$

Therefore

$$
S Z_{t} / 0.9+\sum_{j} a n_{j t}=\sum_{j} a k_{j t}
$$


For the municipality $i$ we obtain:

$$
S Z_{i t}=\left(S Z_{t} / 0.9+\sum_{j} a n_{j t}-\sum_{j}^{n-i} a k_{j t}-a n_{i t}\right) * 0.9
$$

We may introduce the parallelism according to equation (4):

$$
\begin{gathered}
S Z_{i t}=0.9 *\left[\left\{E L_{t}^{*}\left(E G_{0}+S Z_{0}\right) /\left(E L_{0}+E G_{0}\right)-E G_{t}^{*}\left(E L_{0}-S Z_{0}\right) /\left(E L_{0}+E G_{0}\right)\right\} / 0.9\right. \\
\left.+\sum_{j} a n_{j t}-\sum_{j}^{n-i} a k_{j t}-a n_{i t}\right]
\end{gathered}
$$

As is the case with the existing system, the cost coefficient and the total fund sum for block grants are determined in this context. The relation of cost coefficients - not their absolute values - should be fixed and the block grants funds should underlie the parallelism. Then the amount of block grants for a municipality is determined by its own indicator structure, the total block grant funds, the need indicators of other municipalities, the sum of all fiscal indicators and its own fiscal capacity indicator. The cost coefficients vary, but the relation between them remains unchanged. Factor 0.9 is given. Therefore, all municipalities in financial need get the same percentage of normative budget deficit equalized.

\section{Consequences for Local Fiscal Equalization in Estonia}

There are several principal implications of the parallelism as a measure to strengthen the fiscal autonomy of municipalities. The parallelism is based on the idea that the assignment of tasks between central government and municipalities should be stable or is expected to be stable. Estonia has to overcome difficulties as the public sector is still in a transformation process. The wish to provide the municipalities with a high autonomy degree conflicts with the practical experience in the country where politicians like to lead and manage its economy and public sector in terms of ad hoc intervention. Therefore, some changes in task performance of municipalities are caused by the fiscal 
interference of the central government. This would be reduced if a certain level of stable parallelism constant exists. One also has to admit that a small country has to cope more often with political, economic and social crises, epidemics, etc. and reactions to them that cannot be much controlled because the causes of such developments are originated abroad.

Moreover, there are political, economic and public management goal conflicts among the central government and the municipalities. A mechanism must be formulated for checking and changing the parallelism. A solution might concern a corridor of change by stipulating the upper and lower levels in the constitution. A negotiation procedure might be installed that leads to a Nash solution in a commission where Estonian municipalities have half of the seats and a voting power which equals that of the central government. The commission has to find a solution within a specified time scope. A referee solution should be foreseen if the commission does not come to terms. For constitutionally fixed (rather rare) cases an emergency procedure may be installed. If such institutional solutions are not available, a parallelism constant might be found for a year where the fiscal stress for central government and municipalities was relatively low. In other words, for that year the own revenues for central government and for municipalities should be determined as the so-called benchmarks.

A further problem implies surrounding the ways to fix the specified grants. They should follow the connexity principle and assist the municipalities with respect to investment and municipality tasks which should have the priorities for the entire public sector. However, they should not sweep out the block grants and by this way skip the parallelism. In addition total minimum amounts of block grants should be fixed. A similar institutional arrangement as stated above might be helpful also in this case. In this way public tasks for which the central government and Estonian municipalities have to perform together can be considered, which include, for example, regional planning, large infrastructure provision etc.

Furthermore, the conditional grants for tasks related to the connexity principle or the assistance of municipalities to perform nationwide important tasks should be fixed at a minimum referring to a base year. It could be a special percentage of all grants of that base year. This amount may grow according to the growth rate of the central government budget. The equalization funds should be determined according to the 
condition shown in equation (4) after fixing the own revenues and the block grants in a base year. A certain level of parallelism constant can also be introduced in a more normative way as choosing normative own revenues and block grants to get a more favourable solution for the municipalities. Through the implementation of the parallelism those municipalities which are suffering from serious fiscal stress especially those located in eastern and southern Estonia - would experience significant gains, when the economic situation improves.

\section{References}

Blankart, C. B. and R. Borck (2004), Local Public Finance: A Survey, Discussion Paper, Economic Series 154, Faculty of Economics, Humboldt University, Berlin.

De Mello, L. R. (2000), Fiscal Decentralization and Intergovernmental Fiscal Relations: A Cross-country Analysis, World Development 28, 365-380.

Eesti Vabariigi põhiseadus. Vastu võetud rahvahääletusel 28. juunil 1992 (RT 1992, 26, 349) jõustunud 3.07.1992. https://www.riigiteataja.ee/ert/act.jsp?id=633949.

Eichhorn, P. and P. Friedrich (1976), Verwaltungsökonomie, Baden-Baden: Nomos.

Friedrich, P., J. Gwiazda and C. W. Nam (2004), Strengthening Municipal Fiscal Autonomy through Intergovernmental Transfers, in: Capello, R. and P. Nijkamp (eds.), Urban Dynamics and Growth, Amsterdam: Elsevier, 691-728.

Friedrich, P. and K. Ramcke (2007), Öffentliche Unternehmen in Estland, Zeitschrift für öffentliche und gemeinnützige Unternehmen 30(1), 89-106.

Friedrich, P. and J. Reiljan (2008), Strategies in the Fiscal Reform of Estonian General Education, Paper presented at the 48th European Congress of the Regional Science Association International, 27-31 August 2008, Liverpool.

Gravelle, H. and R. Rees (1992), Microeconomics, London: Longman.

KOKS. Kohaliku omavalitsuse korralduse seadus. Vastu võetud 02.06.1993. a seadusega (RT I 1993, 37, 558).

Lenk, T. (2008), Reform des deutschen Länderfinanzausgleichs - eine unendliche Geschichte?, Position Liberal 28, Potsdam: Friedrich Naumann Stiftung. 
Nam, C. W., R. Pasche and M. Steinherr (2001), The Principle of Parallel Development of State and Municipalities as Useful Benchmarks for the Determination of Intergovernmental Grants in Germany, European Planning Studies 9, 525-537.

Reiljan, J., K. Ramcke and K. Ukrainski (2006), Spatial Disparities in Central Governmental Grants to Local Governments, in: Liu, G. V. (ed.), Perspectives on International, State and Local Economics, Hauppauge (NY): Nova Science Publishers, 85-114.

Riigieelarve seadus. Vastu võetud 9. 06. 1999. a seadusega ( RT I 1999, 55, 584)

Seletuskiri kohaliku omavalitsuse üksuse finantsjuhtimise seaduse eelnõu juurde, EV Rahandusministeerium, 2008.

Ulst, E. (2000),. Eesti kohalike omavalitsuste tuludebaasi analüüs. Leping LMJRI 10699, EMFA komponent PA-3 lõpparuanne, okt.

Valla- ja linnaeelarve seadus. Vastu võetud 16. 06. 1993. a seadusega (RT I 1993, 42, 615), jõustunud 1. 01. 1994.

Zimmermann, H. (1999), Kommunalfinanzen, Baden-Baden: Nomos. 


\section{CESifo Working Paper Series}

for full list see www.cesifo-group.org/wp

(address: Poschingerstr. 5, 81679 Munich, Germany, office@cesifo.de)

2737 Hans Jarle Kind and Frank Stähler, Market Shares in Two-Sided Media Industries, July 2009

2738 Pamela Campa, Alessandra Casarico and Paola Profeta, Gender Culture and Gender Gap in Employment, August 2009

2739 Sebastian Gechert, Supplementary Private Health Insurance in Selected Countries: Lessons for EU Governments?, August 2009

2740 Leif Danziger, Endogenous Monopsony and the Perverse Effect of the Minimum Wage in Small Firms, August 2009

2741 Yan Dong and John Whalley, A Third Benefit of Joint Non-OPEC Carbon Taxes: Transferring OPEC Monopoly Rent, August 2009

2742 Valentina Bosetti, Carlo Carraro and Massimo Tavoni, Climate Change Mitigation Strategies in Fast-Growing Countries: The Benefits of Early Action, August 2009

2743 Christina Felfe, The Willingness to Pay for Job Amenities: Evidence from Mothers' Return to Work, August 2009

2744 Jörg Franke, Christian Kanzow, Wolfgang Leininger and Alexandra Väth, Effort Maximization in Asymmetric N-Person Contest Games, August 2009

2745 Bruno S. Frey and Paolo Pamini, Making World Heritage Truly Global: The Culture Certificate Scheme, August 2009

2746 Frank N. Caliendo, Is Social Security behind the Collapse of Personal Saving?, August 2009

2747 Caterina Liesegang and Marco Runkel, Corporate Income Taxation of Multinationals and Fiscal Equalization, August 2009

2748 Chrysovalantou Milliou and Apostolis Pavlou, Upstream Horizontal Mergers and Efficiency Gains, August 2009

2749 Rüdiger Pethig and Christian Wittlich, Interaction of Carbon Reduction and Green Energy Promotion in a Small Fossil-Fuel Importing Economy, August 2009

2750 Kai Carstensen, Oliver Hülsewig and Timo Wollmershäuser, Monetary Policy Transmission and House Prices: European Cross-country Evidence, August 2009

2751 Olaf Posch, Explaining Output Volatility: The Case of Taxation, August 2009 
2752 Beatrice Scheubel, Daniel Schunk and Joachim Winter, Don't Raise the Retirement Age! An Experiment on Opposition to Pension Reforms and East-West Differences in Germany, August 2009

2753 Daniel G. Arce, Dan Kovenock and Brian Roberson, Suicide Terrorism and the Weakest Link, August 2009

2754 Mario Larch and Wolfgang Lechthaler, Comparative Advantage and Skill-Specific Unemployment, August 2009

2755 Horst Raff and Nicolas Schmitt, Buyer Power in International Markets, August 2009

2756 Seppo Kari, Hanna Karikallio and Jukka Pirttilä, The Impact of Dividend Taxation on Dividends and Investment: New Evidence Based on a Natural Experiment, August 2009

2757 Mirco Tonin and Michael Vlassopoulos, Disentangling the Sources of Pro-social Behavior in the Workplace: A Field Experiment, August 2009

2758 Nicole Grunewald and Inmaculada Martínez-Zarzoso, Driving Factors of Carbon Dioxide Emissions and the Impact from Kyoto Protocol, August 2009

2759 Yu-Fu Chen and Michael Funke, Booms, Recessions and Financial Turmoil: A Fresh Look at Investment Decisions under Cyclical Uncertainty, August 2009

2760 Jan-Egbert Sturm and Jakob de Haan, Does Central Bank Communication really Lead to better Forecasts of Policy Decisions? New Evidence Based on a Taylor Rule Model for the ECB, August 2009

2761 Larry Karp, Sacrifice, Discounting and Climate Policy: Five Questions, August 2009

2762 Marianna Belloc and Samuel Bowles, International Trade, Factor Mobility and the Persistence of Cultural-Institutional Diversity, August 2009

2763 Charles Noussair and Fangfang Tan, Voting on Punishment Systems within a Heterogeneous Group, August 2009

2764 Birgit Bednar-Friedl and Karl Farmer, Internationally Coordinated Emission Permit Policies: An Option for Withdrawers from the Kyoto Protocol?, August 2009

2765 Pierre M. Picard and David E. Wildasin, Labor Market Pooling, Outsourcing and Labor Contracts, August 2009

2766 Stefan Voigt and Lorenz Blume, The Economic Effects of Federalism and Decentralization - A Cross-Country Assessment, August 2009

2767 David S. Jacks, Christopher M. Meissner and Dennis Novy, Trade Booms, Trade Busts, and Trade Costs, August 2009 
2768 Mario Jametti and Thomas von Ungern-Sternberg, Hurricane Insurance in Florida, August 2009

2769 Alessandro Balestrino, Kind of Black: The Musicians’ Labour Market in Italy, August 2009

2770 Yosr Abid Fourati and Cathal O’Donoghue, Eliciting Individual Preferences for Pension Reform, August 2009

2771 Christian Breuer and Chang Woon Nam, VAT on Intra-Community Trade and Bilateral Micro Revenue Clearing in the EU, August 2009

2772 Choudhry Tanveer Shehzad, Jakob De Haan and Bert Scholtens, Growth and Earnings Persistence in Banking Firms: A Dynamic Panel Investigation, August 2009

2773 Erdal Yalcin, Uncertain Productivity Growth and the Choice between FDI and Export, August 2009

2774 Klaus Abberger, Wolfgang Nierhaus and Shynar Shaikh, Findings of the Signal Approach for Financial Monitoring in Kazakhstan, September 2009

2775 Sascha O. Becker, Francesco Cinnirella and Ludger Woessmann, The Trade-off between Fertility and Education: Evidence from before the Demographic Transition, September 2009

2776 Thomas Aronsson and Erkki Koskela, Optimal Income Taxation, Outsourcing and Policy Cooperation in a Dynamic Economy, September 2009

2777 Joel Slemrod, Old George Orwell Got it Backward: Some Thoughts on Behavioral Tax Economics, September 2009

2778 Cagri Seda Kumru and Athanasios C. Thanopoulos, Social Security Reform and Temptation, September 2009

2779 Alessandro Bucciol and Roel M. W. J. Beetsma, Inter- and Intra-generational Consequences of Pension Buffer Policy under Demographic, Financial and Economic Shocks, September 2009

2780 Eduardo Strube and Marcelo Resende, Complementarity of Innovation Policies in the Brazilian Industry: An Econometric Study, September 2009

2781 Henry Tulkens and Vincent van Steenberghe, "Mitigation, Adaptation, Suffering": In Search of the Right Mix in the Face of Climate Change, September 2009

2782 Maria L. Loureiro, Anna Sanz-de-Galdeano and Daniela Vuri, Smoking Habits: Like Father, Like Son, Like Mother, Like Daughter, September 2009

2783 Momi Dahan, Tehila Kogut and Moshe Shalem, Do Economic Policymakers Practice what they Preach? The Case of Pension Decisions, September 2009 
2784 Eytan Sheshinski, Uncertain Longevity and Investment in Education, September 2009

2785 Nannette Lindenberg and Frank Westermann, How Strong is the Case for Dollarization in Costa Rica? A Note on the Business Cycle Comovements with the United States, September 2009

2786 Leif Danziger, Noncompliance and the Effects of the Minimum Wage on Hours and Welfare in Competitive Labor Markets, September 2009

2787 Gerlinde Fellner, Rupert Sausgruber and Christian Traxler, Testing Enforcement Strategies in the Field: Legal Threat, Moral Appeal and Social Information, September 2009

2788 Gabriel J. Felbermayr, Mario Larch and Wolfgang Lechthaler, Unemployment in an Interdependent World, September 2009

2789 Sebastian G. Kessing, Federalism and Accountability with Distorted Election Choices, September 2009

2790 Daniel Gros, Global Welfare Implications of Carbon Border Taxes, September 2009

2791 Louis N. Christofides, Michael Hoy and Ling Yang, The Gender Imbalance in Participation in Canadian Universities (1977-2005), September 2009

2792 Jan K. Brueckner and Robert W. Helsley, Sprawl and Blight, September 2009

2793 Vidar Christiansen and Stephen Smith, Externality-correcting Taxes and Regulation, September 2009

2794 John Beirne, Guglielmo Maria Caporale, Marianne Schulze-Ghattas and Nicola Spagnolo, Global and Regional Spillovers in Emerging Stock Markets: A Multivariate GARCH-in-mean Analysis, September 2009

2795 Rüdiger Pethig and Frieder Kolleß, Asymmetric Capital-Tax Competition, Unemployment and Losses from Capital Market Integration, September 2009

2796 Ngo Van Long, Horst Raff and Frank Stähler, Innovation and Trade with Heterogeneous Firms, September 2009

2797 Margit Osterloh and Bruno S. Frey, Research Governance in Academia: Are there Alternatives to Academic Rankings?, September 2009

2798 Thiess Buettner and Clemens Fuest, The Role of the Corporate Income Tax as an Automatic Stabilizer, September 2009

2799 Annette Alstadsæter, Measuring the Consumption Value of Higher Education, September 2009

2800 Peter Friedrich, Chang Woon Nam and Janno Reiljan, Local Fiscal Equalization in Estonia: Is a Reform Necessary?, September 2009 